\title{
HLF wt Allele
}

National Cancer Institute

\section{Source}

National Cancer Institute. HLF wt Allele. NCI Thesaurus. Code C97557.

Human HLF wild-type allele is located in the vicinity of $17 q 22$ and is approximately $60 \mathrm{~kb}$ in length. This allele, which encodes hepatic leukemia factor, plays a role in the modulation of transcription. A chromosomal translocation $\mathrm{t}(17 ; 19)(\mathrm{q} 22 ; \mathrm{p} 13.3)$ with the TCF3 gene is associated with childhood pre-B-cell acute lymphoblastic leukemia. 